\title{
The Protective Role Of Royal Jelly Against Sodium Nitrate And Sun-Set Yellow Toxcity In Albino Rats
}

\author{
Eman G. E. Helal \\ Dept. of Zoology, Fac. of Science for girls, Al-Azhar University,
}

\begin{abstract}
In last few years, all over the world, food preservatives and favorable food colour are used in wide scale. However, their use in food still controversial.

It causes and will cause severe tension to the consumers as the sensitivity of people to general health increases.

This work was carried out to study the possible toxic effect of the interaction of one of food preservatives (sod. nitrite ) and one of the most favorable food colour (sunset yellow) on rates. To study the effect of this interaction, a mixture of $1 / 10$ of the limited dose of $\mathrm{Na} \mathrm{No}_{3}$ and sun-set yellow was daily administered to rats. Other group was supplemented with royal jelly in combination with the mixture to evaluate its possible protective role during the course of experiment. Treatments were continued to 30 days, then half of the animals were sacrificed, the other half was left for 15 days after the last dose without any additional treatment (as a recovery period). The result can be summarized as follows:
\end{abstract}

1. Administration of sod. nitrite and sun-set yellow produced a significant decrease in percentage of body weigh, W.B.Cs, R.B.Cs, Hb, Hct, inorganic phosphorus, serum protein and serum albumin of rats.

2. A marked increase in respiration rate, serum glucose, $T_{3}, T_{4}$, calcium, $\gamma$-GT, LDH, CPK, alk. ph., serum cholesterol and (brain, liver and heart cholesterol) was recorded during treatment with the mixture.

3. Insignificant change in organ / b.wt., heart beat, rectal temperature, serum and tissue AST and ALT, serum acid phosphates, tissue proteins, serum and tissue total lipids muscle and kidney cholesterol and serum triglycerides was determined.

4. Administration of royal jelly and to some extent a recovery period ameliorated many hazards produced by using food additives. So, this study threw light on the bad behavior and its hazards of using food additives and food colour in the same time by our kids. It is also clear that royal jelly as a natural product nearly ameliorate these damage. So, it's advisable to administered royal jelly to children and prevent if possible the using of additive and synthetic colour in their food. 


\section{Introduction}

Nitrites are used as human food additives, mainly for production of specific flavour, formation of charact eristic colour and for preservation of meat products and canned meat under prescribed limitation against the chan ges of botulism (Wolff and Wasserman, 1972, and Laver, 1991). For the same purposes, nitrites are added to some extent to fish and dairy products.

Nitrites could be formed in food stuffs, as well as in the environment and in the human body itself by nitrifying and denitrifying micro-organisms (Asali -na et al., 1971 and Friedman et al., 1972).

The formation of nitrosamines has been demonstrated under natural conditions from secondary amines and nitrite in the presence of certain bacteria present in the humans digestive tract and urinary tract infection (Alam et al., 1971).

Colorants play a significant role in enhancing the aesthetic appeal of food. Foods that are aesthetically pleas ing are more likely to be consumed and to contribute to varied diet and hence better nutrition (Newsome, 1968). Altho -ugh the importance of food colorants, a wave of awareness and concern about many adverse effects of synthetic food colorants on human health is growing. In Egypt, there has been a sharp increase in the use of synthetic food colorants in the past few years (Saleh, 1994).

Dangers of food preservatives and dyes, urged for searching for natural substances that may have an antagonistic action against the hazard ous effects of food colorants. So in this demonstration, royal jelly was tested as a protective agent. Royal jelly is a thick milky food secreted by young nursing worker of bee. It is composed of moisture $(66.05 \%)$, protein $(12.34$ $\%)$, total reducing substances (12.49 $\%$ ), and vitamins (Young and Cho, 1977). Ether extract from royal jelly was free fatty acid, $(68.5 \%)$ of which was 10-OH-2- decenoic acid which is considered as the purity index of the royal jelly. It also contained abundant vital minerals such as $\mathrm{Na}, \mathrm{K}, \mathrm{P}, \mathrm{Mg}, \mathrm{Ca}$, $\mathrm{Mn}, \mathrm{Fe}$ and $\mathrm{Zn}$ (Wen and Hwany, 1994). Organic acid of royal jelly has bacteriostatic activity (Bonvehi and Jouda, 1991). Sayer et al. (1996) reported the immune modulator potential of royal jelly in rats and mice.

It has been noticed that children used to have food and drinks which contain food preservatives and colorants at the same time. This behavior attrac ted my attention to study the interaction between food preservatives and colora nts. Since, sodium nitrite is one of the most famous food preservative and sunset yellow is one of the most attractive colorants. I mixed limited dose of each and tested it on rats. I found that the interaction of the limited dose of each gave a new compound with lethal dose. Hence, this study was planned to invest -igate the effect of this new compound on physical, hematological and biochem -ical parameters of male albino rats, as well as the effect of royal jelly as antid ote to this new compound. And to see if it could ameliorate the expected hazards.

\section{Material and methods}

Thirty growing male albino rats aged about one month were used in this work. They were randomly divided into three groups of 10 rats each. All groups were kept in wire cages under the same condition. Fresh tap water and standard 
rodent diet were provided ad libitum throughout the experimental periods.

The first group served as control group. The second group were received $10 \mathrm{mg} \mathrm{NaNo}_{3}$ and $0.5 \mathrm{mg}$ sun-set yellow (S.S.Y) $/ \mathrm{kg}$ daily for a month. The third group received the same dose of $\mathrm{NaNo}_{3}$ and S.S.Y in addition to 100 $\mathrm{mg} / \mathrm{kg}$ royal jelly (R.J). All treated doses were given by gastric intubations to each rat.

Body weights, respiration rate, heart beats and rectal temperature were recorded once a week throughout the experimental period. After 30 days of treatment, Five animals of each group were decapitated. While the other half of each group was kept for two weeks, without any additional treatment for recovery.

At the end of the experiment, the animals were weighed and killed by decapitation. Liver, brain, kidney, heart and testis were removed, cleaned from adherent tissues and weighed at once. Pieces of liver, skeletal muscle, kidney, heart and brain were weighed and put in an appropriate amount of $30 \%$ potass ium hydroxide for total protein determi -nation. Another pieces were put in concentrated sulfuric acid for total lipid determination.

Blood samples were collected for hematological and biochemical analysis. EDTA, an anticoagulant, was added to the collected blood for hemat ological parameters, while the blood samples for biochemical parameters were centrifuged for $10 \mathrm{~min}$. at 5000 rpm and supernatant sera were separa ted for analysis without storage or delay. Hemoglobin concentration was determined according to Van-Kampen and Zulstra (1961). Red and white blood cells were counted and Haemat ocrit values (Hct) were estimated using the technique of Rodak (1995). The biochemical analysis were carried out on the blood sera.

Glucose determination was based on the enzymatic method desc ibed by Siest and Schielf (1991). AST and ALT activities were accomplished using the method of Reitman and Frankel (1975). Gamma- glutamyl tran -speptidase was estimated by the method of Meister et al. (1981). While, Lactic dehydrogenase (LDH) activity was determined according to Raabo (1963). Creatin phosphokinase assay was performed using sigma chemical company reagent kits (St. Louis Mo). Alkaline phosphatase activity was meas -ured according to the method of Belfield and Goldberg (1971). The activity of plasma acid phosphatase was determined according to the method of Tietz (1986). Thyroid hormones assay were determined by using the enzymelinked immunosorbent assay (ELZSA) (Whitly et al., 1996). Inorganic phosp horus was determined according to the method of Fisk and Subbarow (1952) and serum calciun $\left(\mathrm{Ca}^{++}\right)$conc entration was estimated according to the method adopted by Ray Sarker and Chauhan (1967). Total proteins were estimated using the Biuret method as described by Doumas (1975). Albumin was determined according to the meth od of Webester (1977). Total lipids were determined according to the method of Knight et al. (1972), while serum cholesterol was determined as mentioned by Fossati and Medici (1987). And serum triglycerides were determined by the method of Rojkin et al. (1974).

Student t-test was used to compare between means of the different experimental animal groups. Significant differences between means of the control and treated groups were cons idered only at $\mathrm{P}<0.05$ (Sokal and Rahif, 1981). 


\section{Results}

The present findings indicated that the group supplemented with sod. nitrite and sun-set yellow (S.S.Y) showed significant body weight loss $(\mathrm{P}<.01)$ after feeding for 30 days, and showed a significant reduction in body weight gain after 15 days of treatment stoppage (post effect)when compared with the weights of the control group. While, royal jelly treated group showed a significant decrease $(\mathrm{P}<.01)$ of the mean body weight gain for the two periods (Table, 1).

There was insignificant changes in the percentage of the mean relative kidney, brain, heart, liver and testis weight of all treated groups (Table, 1).

Furthermore, no significant diffe -rences were recorded either in rectal temperature, in respiration rate or heart rate of all treated groups as compared with the control one at different experi mental periods (Table,2).

The number of WBCs as well RBCs, $\mathrm{HB} \%$ and Hct \% were signific antly decreased $((\mathrm{P}<.01)$ after 30 days of treatment with both $\mathrm{NaNo}_{3}$ and S.S.Y This decrease continued even after the 15 days period where the animals were left for recovery. Daily treatment with royal jelly for 30 days produces insig nificant change in all hematological parameters tested when compared with the control group even after the recovery period (Table, 3 ).

The group treatment with both sodium nitrite and sun-set yellow induced a significant increase of serum glucose level throughout the experim ental period. When animals were administered royal jelly in addition to the mixture of additives, no significant change in serum glucose was recorded (Table, 4).

In relation to thyroid function, the data obtained showed that $\mathrm{NaNo}_{3}$ and S.S.Y ingestion for 30 days led to a significant increase $(\mathrm{P}<.01)$ as indicated by higher serum T3 and T4 concent rations than that in control group (Table, 4). On the other hand, royal jelly caused insignificant change in serum T3 and T4 level as compared with the control group (Table, 4).

Table (4) showed calcium and inorganic phosphorous contents in control, a mixture $\left(\mathrm{NaNo}_{3}+\mathrm{S} . \mathrm{S} . \mathrm{Y}\right)$, and in mixture with royal jelly treated gro ups after 30 days of treatment and 15 days post-treatment. Serum calcium level was significantly increase $(\mathrm{P}<.01)$ after both treated and recovery periods. Rates treated with royal jelly in combination with food additives show ed insignificant change in serum calc ium level throughout the experimental period. The data showed that the inorganic phosphorus level increased significantly $(\mathrm{P}<.01)$ in the groups treated with $\left(\mathrm{NaNO}_{3}+\right.$ S.S.Y $)$ and $\left(\mathrm{NaNo}_{3}+\right.$ S.S.Y + R.J ) as compared with the control group. After the recovery period, serum inorganic phosp -horus level in treated group $\left(\mathrm{NaNo}_{3}+\right.$ S.S.Y) showed a significant increase $(\mathrm{P}<.01)$, while the group treated with royal jelly, in addition to the mixture, showed insignificant change in compa rison with the control group.

Concerning AST and ALT activities of serum and tissues, no appreciable changes have been recorded (data was in normal value) in all treated groups throughout the experimental period ( Tables, $5 \& 6$ ).

Table (7) depict enzyme activities in serum of different rat groups. CPK, $\gamma$-GT and alk. phosphates activities were found to be significantly increased $(\mathrm{P}<.01)$ in rats treated with $\left(\mathrm{NaNO}_{3}+\right.$ S.S.Y). The effect of the mixture $\left(\mathrm{NaNO}_{3}+\right.$ S.S.Y $)$ on serum 
LDH activity was significant increase $(\mathrm{P}<.01)$ after treated period only. Furthermore, serum acid phosphates activity was insignificant in all treated groups as compared with the control group. On the other hand, no detectable changes were observed in all the detected enzyme activities of our study in the group treated with royal jelly in addition to $\left(\mathrm{NaNo}_{3}+\right.$ S.S.Y) after the two periods of the experiment.

The treated group with sod. Nitrite and S.S.Y for one month caused significant decrease $(\mathrm{P}<.01)$ in total serum protein and serum albumin (Table, 8). The animals fed with royal jelly for one month of treatment with $\left(\mathrm{NaNo}_{3}+\right.$ S.S.Y), no significant changes were observed in the concentration of serum total protein and serum albumin. Moreover, no significant change was recorded after the recovery period (15 days). The serum globulin level of all treated groups was not changed after 30 days of treatment. Yet, it is significantly decreased $(\mathrm{P}<.05)$ in all treated groups after the recovery period. The $\mathrm{A} / \mathrm{G}$ ratio level in rats treated with mixture of $\left(\mathrm{NaNo}_{3}+\right.$ S.S.Y) induced insignificant change throughout the experimental period. When rats treated with the mixture and royal jelly for one month, the level of $A / G$ ratio was significantly increased $(\mathrm{P}<.05)$. This decrease was more pronounced $(\mathrm{P}<.01)$ after the recovery period. On the other hand, total protein level in all tested organs was insignificantly change in all groups till the end of the experiment (Table, 8).

The treatment of rats with the mixture $\left(\mathrm{NaNo}_{3}+\mathrm{S} . \mathrm{S}\right.$.Y $)$ or the mixture with royal jelly induced insignificant changes of serum and tissues total lipids level of all treated animal group till the end of the experiment (Table, 9). Total cholesterol in serum was significantly elevated $(\mathrm{P}<.05)$ in rats treated with
$\left(\mathrm{NaNo}_{3}+\right.$ S.S.Y) after 30 days of treatment. Total cholesterol in brain, liver and heart, however, recorded highly significant elevation $(\mathrm{P}<.01)$ after 30 days of treatment with the mixture. On the other hand, muscle and kidney cholesterol did not induce any significant change in all treated groups. After the recovery period (15 days posttreatment ) cholesterol level of serum, liver, brain and heart was turn back to the normal value.

In conclusion, using of the royal jelly ameliorated the hazard effects of the mixture on serum and tissues cholesterol level, where no significant change were recorded (Table, 10).

\section{Discussion}

The present results revealed a significant decrease in body weight after one month of treatment and 15 days of recovery for all treated groups. These results were in agreement with those reported by Lachikawa et al.(1971) and Hirose et al. (1993). They recorded a decease in body weight gain of rats receiving different doses of sodium nitrite. Yet, Greenblatt and Lijinsky (1972) working on male mice and Van logten et al. (1972) working on rat observed a decrease in body weight gain in the rats receiving a canned meat treated with sodium nitrite. Yoshida et al. (1994) recorded that rats treated with ascorbic acid or sodium ascorbate individually or in presence of sodium nitrite showed a reduction of final body weight. In addition, Shaker and cowork -ers (1989) found that the supplem entation of chocolate brown to the casein diet of rats significantly reduce their body weight after 15 days of feeding. The present results did not show statistically significant changes of the relative weight of the tested organs of the male rats treated with sod. nitrite 
and sun-set yellow or with sod. nitrite, sun-set yellow and royal jelly. Hirose et al. (1993); Fujitani (1993) and Yoshida et al. (1994) reported an increase of absolute and relative liver and kidney weights of rats treated with sod. nitrite. These results are not in harmony with those of the present study.

Concerning heart beat, rectal temperature and respiratory rate in all treated groups, no significant changes were recorded allover the experimental period.

Alterations of the various hemat -ological parameters in blood of the studied rats were also investigated. These changes induced by $\mathrm{NaNo}_{3}$ and food colorant may be due to the prevention of red blood cell synthesis via inhibition of erythropoiesis in the bone marrow. In agreement with the present work, Mason et al. (1974), demonstrated a reduction of hemoglobin when carmoisine was administered to the diet of mice. The present observ -ation of low hemoglobin level may be due to decrease of food intake which leads to insufficiency of protein and / or iron content and their lesser utilization, that hemoglobin synthesis depends on. These observation may by due to that nitrite causes changes in the size of red blood cells. These changes may be related to its effect on hemoglobin (Shuval and Gruener, 1972).

The present results for hemogl obin and hematocrite values are is agree -ment with those reported by Til et al. (1988). Also, Grant and Butler (1989) observed that hemoglobin content and hematocrite value showed a tendency toward a lower values in rats received different doses of nitrite.

Treating rats with both sod. nitrite and sun-set yellow induced a significant increase in the blood sugar level. However, one can expect that sod. nitrite produced hyperglycemia due to deficiency of insulin release. It is known that nitric oxide is formed from nitrites at least by the vascular epithelial cells (Harrison and Bates, 1993 and Katzung 1995). Both nitric oxide and nitrites open potassium channel (Kanzung, 1995), which through closing voltage gated calcium channels decre -ases intracellular calcium. Calcium is known to trigger insulin secretion, calci -um channel blockers are known to prod -uced hyperglycemia ( Katzung, 1995).

The present results go in parallel with those reported on the hypergly cemic effect of sodium nitrite in rats (Abdel-Rahim et al, 1988 and Shelpov et al., 1991). They reported that in presence of nitric ion, the activity of amylase increases beside an inhibition of adrenaline-induced activation of phosphorylase. This results in the liberation of glucose from glycogen, so blood glucose increases while liver glycogen decreases.

The elevation of level of serum glucose was also interpreted by the effect of sun-set yellow on enzyme syst -em of the glycolytic pathway. It is not surprising to find an enhanced hyperg lycemia due to the new compound resul -ted from the reaction of sodium nitrite and sun-set yellow treatment of the rats. The observed improvement shown in glucose in royal jelly treated group may be due to its action as antioxidant.

The degradation process of body weight in rats fed on $\mathrm{NaNo}_{3}$ and S.S.Y paralleled the significant increase in activity of thyroxin $T_{3}$ and $T_{4}$ hormones of the thyroid gland. The present investi -gation is supported by the findings of El-Saadany (1991) who found that synthetic colorants (Chocolate; Indigoca -rmine and Carmoisine) significantly increased T4 hormone. He suggested that hyperthyroidism may play a signi - 
ficant role in the genesis of decreased serum lipids content of rats fed on these synthetic chocolate colorants. There exists a positive correlation between relative body weight and plasma conce ntrations of lipids ( Harper et al., 1993). Therefore, the reduction of body weight may be attributed to the stimulation of thyroid gland through alteration in the pituitary-thyroid axis as a consequence of the stressing effects induced by the feed additives which may be stern an increase in rate of release or formation of thyroid stimulation hormone by the pituitary gland, elevating $\mathrm{T}_{4}$ value, ther -eby increasing energy expenditure whi -ch would account for decreasing the fat pattern metabolism (Abdel Rahim et al., 1993)

In the current study, the mechanism by which sodium nitrite altered thyroid function is still uncer tain. It could be proposed that nitrite may enhance intrathyroidal synthesis of thyroid hormones and increases the extrathyroidal conversion of $\mathrm{T}_{3}$ and $\mathrm{T}_{4}$ meanwhile, nitrites may attenuate the binding capacity of thyroid binding proteins for thyroid hormones (Heiba shy and Abd El- Moneim, 1999).

The present study revealed that administration of sod. nitrite and sun-set yellow to rats caused variable degree of stimulation of thyroid gland function after treated and recovery periods. This was proved by the significant increase in serum thyroid hormones $\mathrm{T}_{3}$ and $\mathrm{T}_{4}$. The interaction between sod. nitrite and sun-set yellow may give a new chemical component, which has a stimulatory effect on thyroid gland. It is also clear that royal jelly ameliorate this effect due to its antioxidant property. This could be by blocking the generation and propagation of free radicals.

The result of this study demo nstrated that the administration of
$\left(\mathrm{NaNo}_{3}+\right.$ S.S.Y) caused a significant increase in serum calcium level. This observation was similarly recorded by Sharma (1989), who recorded higher values of minerals in rats treated with metanil yellow. On the other hand, the present results showed a significant decrease in serum phosphate after treat ment with the mixture of $\left(\mathrm{NaNo}_{3}+\right.$ S.S.Y) during the treated period, while after the recovery period it turned back to the normal value in royal jelly treated group. Helal et al. (2000) stated that S.S.Y did not affect serum level of both $\mathrm{Ca}$ and $\mathrm{Ph}$. So, the present results may be due to the new compound resulted from the reaction between both $\mathrm{NaNO}_{3}$ and S.S.Y.

Measurements of certain enzy me activities in the blood are of great value in liver diseases but their investigation is complicated by many factors including the existence of isoenz -ymes, their rate of disappearance by excretion or destruction, their rate of release from cells due to increased perm -eability or obstruction of the ducts of secretory organs, as well as increased enzyme synthesis, perhaps associated with regeneration.

AST and ALT activities of serum and tissue were still in normal range in all treated groups. In harmony with these findings, (Ford et al., 1987), stated that tartrazine and carmoisine caused insignificant changes in rat serum AST and ALT. The liver cells also play an important role in both synthesis and secretion of $\gamma$-GT and alk. phosphates. Therefore, the alteration in their activities are attributed to early cholestatic liver damage which prim arily affects the liver parenchyma, thus making alk. phosphatase and $\gamma$-GT sensitive indices in the early diagnosis of infiltrate diseases (El-Elaimy and ElNabi, 1990). 
In the present work, both $\gamma$-GTand alk. phosphatase were increased in the group of rats given $\left(\mathrm{NaNo}_{3}+\right.$ S.S.Y). However, the significant reduction in $\gamma$ GT and alk . phosphatase activities in royal jelly treated group may be due to its protective role against the marked effect of the mixture on liver.

The elevation of serum CPK and $\mathrm{LDH}$ in a mixture $\left(\mathrm{NaNO}_{3}+\mathrm{S} . \mathrm{S} . \mathrm{Y}\right)$ treated rats, could be attributed to a generalized increase in membrane permeability and is particularly useful in the diagnosis of muscular disorder, especially progressive muscular dystr ophy (Doran and Wilkinson, 1975; Ebashi et al., 1959). The insignificant increase of acid phosphatase in the present findings is in accordance with Singh and Khanna (1979), who found no marked alteration in the hepatic and serum activities of GPT, GOT and acid phosphatase in rats fed orange II.

A significant decrease of the total serum protein was recorded after treatment with the mixture of $\mathrm{NaNO}_{3}+$ S.S.Y for one month. The decrease of total serum protein due to the mixture treatment was reflected on serum albu min level where a remarkable decrease was recorded. This decrease may be resulted from liver function impairment induced by the nitrite. The globulin fraction, on the other hand, was not affected generally at the same time, but it was affected after the recovery period. Supplementation rats with both royal jelly and the mixture lead to a decrease in globulin all over the experimental time and an increase $\mathrm{A} / \mathrm{G}$ ratio after the recovery period.

Eremin and Yocharina (1981) reported the harmful effect of nitrite which reflected on the biosynthesis of protein. They recorded a decrease in serum protein of rats due to the stimul atory effect of the nitrite on the thyroid and adrenal gland, which leads to block of protein synthesis while fast break down, occurs. In agreement with our results, Sharma (1989) and Mackenzie et al., (1992) recorded a significant reduction in serum protein after administration of metanil yellow or caramel to rats, respectively

Effects of nitrite and sun-set yellow on most of the tested parameters were significantly counteracted by oral administration of royal jelly as comp ared with the non treated control group.

The lipid profile of the studied rats revealed a significant increase in serum, brain, liver and heart cholesterol, while no significant change was recorded in serum and organs total lipids. The present hypercholes terolemia in combination with normal total lipids level may be resulted in elevation of the risk ratio in the mixture treated rats, make the new component (within the mixture) a potential incrim inates for risk of ischemic heart disease. In accordance with these observations it was reported that hypercholsterolemia (Schaefer et al., 1981) has been consi dered as risk factors and important diagnostic criteria in differentiating indi -viduals with coronary heart disease. Royal jelly supplementation prevented the elevation of cholesterol profile. Also, after the recovery period chole sterol levels of serum, brain, liver and heart were return back to their baseline values. So, it is advisable to supplement royal jelly simultaneously to kids who are at high risk of food additives inte raction to alleviate their toxic effects.

It is known that in Egypt there is sometimes uncontrolled use of food additives particularly in food consumed mainly by children, hence the safe use of those compounds should be investi gated. Cooperation between public health authorities and other ministries concerned with food safety is necessarylegislation and specification of 
food additions should be always carried out.

\section{References}

1. Abdel-Rahim, E.A. Ashoush, Y.A.; Afify, A.S. and Hewedi, F. (1993). Effect of some synthetic food additives on blood haemoglobin and liver function of rats. Minufiya J. Agric. Res., 12(1): 557.

2. Abdel-Rahim, E.A.; El-desoky, G.E.; Shaban, O.A. and Afify, A.S. (1988). Studies on the effect of sodium nitrite on hemoglobin fractions and growth rate of albino rats. Bull. Fac. Agric. Univ., Cairo, 39(4):1253-1561.

3. Alam, B.S.; Saporoschetz, I.B. and Epstein, S.S, (1971). Formation of $\mathrm{N}$-nitrosopiperidine from piperidin and sodium nitrite in the stomach and isolated intestinal loop of the rat. Nature, $232: 116$.

4. Asalina, S.; Friedmen, M.; Arnold, E.; Miller, G.; Mishkin, M.; Bishop, Y. and Epstein, S.S. (1971). Acute synergistic toxicity and hepatic necrosis following oral adminis -tration of sodium nitrite and secondary amines to mice. Cancer Res., 31: 1201-1205.

5. Belfield, A. and Goldberg, D.M. (1971). Hydrolysis of adenosinemonophosphate by acid phosphatase as measured by continuous spectrophotometric assay. Enzyme, 12: 561 .

6. Bonvehi, J.S. and Jouda, R.E. (1991). Organic acids influence on microbiological quality and bacter iostatic activity of royal jelly. Deutsch. Lebensm. Rundsch., 87: 216-229.

7. Borzelleca, J.F. and Hallagen, J.B. (1988). A chronic toxicity / carcinogenicity study of FD \& C yellow NO.5 (tetrazine) in mice. FD. Chem. Toxic., 26(3):189-194.

8. Doran, G. R. and Wilkinson, J.H. (1975). The origin of the elevated activities of creatine kinase and other enzymes in the sera of patients with myxoedema. Clin. Chem. Acta, 62: 203.

9. Doumas, B.T. (1975). Standards for total serum protein assayes A collaborative study. Clin. Chem., 21(8): 1159-1161.

10. Ebashi, S.; Toyokura, Y.; Momoi, H. and Sugita, H. (1959). High creatine phosphokinase activity of serum of patients with progressive muscular dystrophy. J. Biochem. (Tokyo), 46: 103.

11. El-Elaimy, A. and El-Nabi, S.E.H. (1990). Influence of thiola on pesticide induced intoxication 11preventive effect of liver damage. J. Environ. Sci., 1: 67-82.

12. El-Saadany, S.S. (1991). Biochemical effect of chocolate colouring and flavoring like substances on thyroid function and protein biosynthesis. Die. Nahrung., 35(4): 335-343.

13. Eremin, Y.N. and Yochorina, M.G. (1981). Effect of nitrites on the thyroid gland of rats in response to different diets of iodine deficiency. Vopr. Pitan., 5: 60-62.

14. Fisk, C.H. and Subbarow, M. (1952). The colorimetric determi nation of phosphorus. J. Biol. Chem., 66: 375-383.

15. Ford, G.P.; Stevenson, B.I. and Evans, J.G. (1987). Long term toxicity study of carmoisine in rats using animals exposed in vitro. Fd. Chem., 25(12): 919925.

16. Fossati, P. and Medici, R.(1987). Abstract book: International Symposium on Cholesterol Control and Radiovascular 
Diseases: Prevention and Therapy. Milan. Italy.

17. Friedman, M.A.; Miller, G.; Sengupia, M. and Epstein, S.S. (1972). Inhibition of mouse liver protein and nuclear RNA synt hesis following combined oral treatment with sodium nitrite and dimethylamine or methylbenzy lamine. Experientia, 28: 21.

18. Fujitani, T. (1993). Short-term effect of sodium benzoate in F344 rat and $\mathrm{B}_{6} \mathrm{C}_{3} \quad \mathrm{~F}_{1}$ mice. Toxicol. Lett., 69(2): 171-179.

19. Grant, D. and Butler, W.H. (1989). Chronic toxicity of sodium nitrite in male F344 rat. Fd. Chem. Toxic., 27(9): 565-571.

20. Greenblatt, M. and Liginsky, W. (1972). Failure to induce tumors in Swiss mice after concurrent administration of amino acids and sodium nitrite. J. Nat. Cancer Inst., 48: 1389-1392.

21. Harper, H. A; Rodwell, V.W. and Mayes, P.A. (1993). Review of physiological chemistry. $17^{\text {th }}$ ed. Middle east edition. Lange medical publications. p. 511-557.

22. Harrison, D.G. and Bates, J. N. (1993). The nitronasodilators: new ideas about old drugs. Circulation, 87: 1461.

23. Heibashy, M.I.A. and Abd ElMoneim, A.E. (1999). Blood lipid profile and serum free thyroidal hormone concentrations in gro wing rats fed diets enriched with sodium nitrite for short and long terms. J. Egypt. Ger. Soc. Zool., 30(A): 93-103.

24. Helal, E.G.E.; Zahkouk, S.A.M. amd Mekawy, H.A. (2000). Effect of some food colours (synthetic and natural products) on liver and kidney functions of young albino rats. The Egyptian Journal of hospital Medicine, 1: 103-113.
25. Hirose, M.; Tanka, H.; Takashi, S.; Fulkuchi, M.; Fukushima, S. and Ito, N. (1993). Effects of sodium nitrite and catechol, 3-methoxy catechol, or butylated hydroxy anisole in combination in rat multiorgan carcinogensis model. Cancer Res., 53: 32-37.

26. Katzung, B.G. (1995). Basic and Clinical Pharmacology. A long medical book, $6^{\text {th }}$ ed., less Altes, California, pp. 199-203.

27. Knight, J.A.; Anderson, S. and Rawle, J.M. (1972). Chemical basis of the sulfophosphovanillin reaction for estimation total serum lipids. Clin. Chem., 18(3): 199-202.

28. Lachikawa, H.; Fugii, T.; Kobayashi, H.; Sakamo, y.; Hayashida, S.; Yoneyama, M.; Ikeda, T. Yano, N.; Konno, T. and Hiraga, K. (1971). Toxicological potentiation studies of food additives subchronic oral toxicity of butylated hydroxyl toluene (BHI). Sodium nitrite and their combination in rates. Ann. Rep. Tokyo-Metropolitan. Res. Lab. Rub. Health. 23: 345-371.

29. Laver, K. (1991). The history of nitrite in human nutrition a contri bution from German cookery books. J. Clin. Epidemiology, 44: 391-392.

30. Mackenzie, K.M.; Boysen, B.G.; Filed, W.E.; petsel, S.R.; Chappel, C.I. and Stanly, J. (1992). Toxicity and carcinogenicity studies of caramel colour IV in $\mathrm{F}_{344}$ rats and $\mathrm{B}_{6} \mathrm{C}_{3} \mathrm{~F}-1$ mice. Food and Chemical toxicology, 30(5): 431-443.

31. Mason, P.L.; Gaunt, I.F..; Butterworth, K.R.; Hardy, J.; Kiss, I.S. and Grasso, P. (1974). Long term toxicity studies of carmoisine in mice. Fd. Cosmet. Toxicol., 12(512): 601-607.

32. Meister, A.; Tate, S.S. and Ffith, G.R. (1981). Gamma-glutam- 
yltranspeptidase. Methods

Enzymol., 77: 237-253.

33. Newsome, R.L. (1968). Food colours. J. Fd. Technol., 40: 4952.

34. Raabo, E. (1963). Determination of serum lactic dehydorgenase by the tertazolium salt method. Scand. J. Clin. Lab. Invest., 15: 233.

35. Ray Sarker, B.C. and Chauhan, U.P.S. (1967). A new method for determining microquantities of calcium in biological materials. Anal. Biochem., 20: 155-166.

36. Reitman, S. and Frankel, S. (1975). A colourimetric method for the determination of serum glutamic oxaloacetic and glutamic pyrovic transaminases. Am. J. Clin. Path., 28: 56.

37. Robert, K. M.; darly, K.G.; peter, A.M. and Viotor, W.R. (1993). Harper's Biochemistry. Lange medical publications, $23^{\text {rd }}$ ed., London, pp. 422-435.

38. Rodak, F.P. (1995). Routine laboratory evaluation of blood cells and bone marrow. In: Diagnostic hematology, pp. 125129, W.B. Saunders Comp. Phild. London, Toronto, Montreal, Sydney, Tokyo.

39. Rojkin, M.L.; Olguin, D.E.; Mariani, M.C.; Drappo, G.A.y. and Sosa, C.P. (1974). Proteinastotales del sureo: causes mas frecuentes de error en la roaccion del Biuret Nuevo reactivo cupraol calino estable. Biog. Del. Atlantico, V. 1163-1193.

40. Saleh, S.H. (1994). Photometric, test for kinetic measurements of creatinine. Deutsch. Med. Wschr., 89: 1018-1640.

41. Sayer, J.M.; Yagi, H.; Wood, A.W.; Conney, A.H. and Jerina, D.M. (1996). Eytreamely facile reaction between ultimate carcinogen benzo (a) pyrene-7.8- diol-9.10. epoxide and ellagic acid. G. Am. Chem. Soc., 04 : 5562-5564.

42. Schaefer, E.J.; Levy, R.I. and Ernst, N.D. (1981): the effects of low cholesterol, high polyunsa turated fat and low fat diet on plasma lipid and lipoprotein cholesterol levels in normal and hyperchol -esterolemic subjects. Am. J. Clin. Nutr., 34: 1758.

43. Sharma, S.D. (1989). Renal gross biochemistry of albino rat influenced by a common food color, metanil yellow. J. Adv. Zool., 10(2): 95-98.

44. Shelpov, V.; Chekulaev, V. and Pasha-Zade, G. (1991). Factors within the body determining the glycogen reserves in the tissues of rats. Biomed. Sci., 2(2): 111120.

45. Shaker, A.M.H.; Ismail, I.A. and Eilnemr, S.E. (1989). Effect of different food stuff colourants added to casein diet on biological evaluation. Bull. Nutr. Inst., Cairo, Egypt, 9(1): 77-86.

46. Shuval, H.I. and Gruener, N. (1972). Epidemiological and toxicological aspects of nitrates and nitrites in the public health association, Minneapolis, Minnesota.

47. Siest, G. and Schielf, M.J. (1991). Interpretation Des Examines de laboratoire, karger ed., pp. 206223.

48. Singh, G.B. and Khanna, S.K. (1979). Toxicity studies in rats fed orange II. Indian J. Exp. Biol., 17(10): 1100-1102.

49. Sokal, R.R. and Rohif, F.J. (1981). Biometry: The Principles and Practice of Statistics in Biological Research. $2^{\text {nd }}$ ed. Freeman, W.H. Company San. Francisco.. 
50. Tietz, N.W. (1986). Text book of Clinical Chemistry, W.B.

Saunder Co., London, Philadelphia

51. Til. H.P.; Fanke, H.G.; kyper, C.F. and Williams, M.Z. (1988). Evaluation of the oral toxicity of potassium nitrite in a 13-week drinking water study in rats. Fd.Chem.Toxic.,26(10):851-859.

52. Van Kamper, E.J. and Zulstra, W.G. (1961). Standardization of hemoglobinometer: the hemoglobin : The cyanide method. Clin. Chem. Acta, : 538 - 540.

53. Van Logten, M. J.; Tonkelaar, F.M. Den.; Kroes, R.; Berkvens, T.M. and Van Esch, G.J. (1972). Long term experiment with canned meat treated with sodium nitrite and glucono-S- Lactone in rats. Fd. Cosmet. Toxicol., 10: 475-488.

54. Webster, D. (1977). Albumin standards and measurement of serum albumin with bromocresol green. Clin. Chem., 23: 663-666.

55. Wen, Hwei-Mei and Hwany, Wening (1994). Quality survey of commercial royal jelly products. J. Food Drug. Anal., 2: 229-234.

56. Whitley, R.J.; Meikle, A.W. and Watts, N.B. (1996).
Endocrinology. In: Teitsz NW. fundamentals of

clinical chemistry. W.B. Saunders Company, Philadelphia, London, Toronto, 673-704.

57. Wolff, I.A and Wasserman, A.E. (1972). Nitrates, nitrites and nitrosamines. Science, 177: 15-19.

58. Yoshida, A.; Hirose, M.; Takaba, K.; Kinura, J. and Ito, N. (1994). Induction and promotion of fores tomach tumors by sodium nitrite in combination with asco -rbic acid or sodium ascorbate in rats with or without N-mehyl-N-nitro-Nnitrosoguandine pretre -atment. Int. J. Cancer, 56: 124-128.

59. Yoshida, Y.1; Harada, T.; Hayashi, S.; Mori, I.; Miyajima, H. and Maita, K. (1994). Endometrial carcinogenesis induced by concurrent oral administration of ethylene-thiourea and sodium nitrite in mice. Carcinogenesis, 15(10): 2311-2318.

60. Young, T. and Cho, M.D. (1977). Studies on Royal jelly and abnormal cholesterol and triglyce rides. American bee Journal, 36: 38

Table (1): The percentage change in body weight and the organ /somatic ratio in control, treated with ( $\mathrm{NaNo}_{3}+$ S.S.Y) and treated with $\left(\mathrm{NaNO}_{3}+\mathrm{S} . \mathrm{S} . \mathrm{Y}+\right.$ royal jelly $)$ after treated and recovery periods in young albino rats.

\begin{tabular}{|c|c|c|c|c|c|c|c|}
\hline \multirow[b]{2}{*}{ Parameter } & \multirow{2}{*}{ 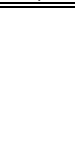 } & \multicolumn{3}{|c|}{ Treated period ( 30 days ) } & \multicolumn{3}{|c|}{ Recovery period (15 days) } \\
\hline & & Control & $\begin{array}{l}\mathrm{NaNO}_{3}+ \\
\text { S.S.Y }\end{array}$ & $\begin{array}{l}\mathrm{NaNO}_{3}+\text { S.S.Y. and } \\
\text { royal jelly }\end{array}$ & Control & $\begin{array}{l}\mathrm{NaNo}_{3}+ \\
\text { S.S.Y }\end{array}$ & $\begin{array}{c}\mathrm{NaNo}_{3}+\mathrm{S} . \mathrm{S} . \mathrm{Y} \\
+ \text { + Royal jelly }\end{array}$ \\
\hline $\begin{array}{c}\text { \% of body } \\
\text { weight } \\
\text { change }\end{array}$ & $\begin{array}{c}X \\
S . E \\
P\end{array}$ & $\begin{array}{l}19.6 \\
0.26\end{array}$ & $\begin{array}{l}-11.9 \\
0.69 \\
<.01\end{array}$ & $\begin{array}{l}16.4 \\
0.60 \\
<.01\end{array}$ & $\begin{array}{c}18.94 \\
0.40\end{array}$ & $\begin{array}{l}10.6 \\
0.40 \\
<.01\end{array}$ & $\begin{array}{l}15 \\
0.70 \\
<.01\end{array}$ \\
\hline $\begin{array}{l}\text { Kidney/ } \\
\text { b.wt }\end{array}$ & $\begin{array}{c}X \\
\text { S.E } \\
P\end{array}$ & $\begin{array}{l}0.70 \\
0.12\end{array}$ & $\begin{array}{l}0.57 \\
0.12 \\
-----\end{array}$ & $\begin{array}{r}0.57 \\
0.13 \\
----\end{array}$ & $\begin{array}{l}0.60 \\
0.13\end{array}$ & $\begin{array}{c}0.57 \\
0.12 \\
----\end{array}$ & $\begin{array}{c}0.58 \\
0.14 \\
----\end{array}$ \\
\hline $\begin{array}{c}\text { Brain / } \\
\text { b.wt }\end{array}$ & $\begin{array}{c}X \\
\text { S.E } \\
P\end{array}$ & $\begin{array}{l}0.86 \\
0.13\end{array}$ & $\begin{array}{c}0.86 \\
0.13 \\
--- \\
\end{array}$ & $\begin{array}{r}0.89 \\
0.13 \\
---- \\
\end{array}$ & $\begin{array}{l}0.90 \\
0.12\end{array}$ & $\begin{array}{l}0.85 \\
0.14\end{array}$ & $\begin{array}{l}0.87 \\
0.14\end{array}$ \\
\hline $\begin{array}{l}\text { Cardio- } \\
\text { somatic } \\
\text { index }\end{array}$ & $\begin{array}{c}X \\
\text { S.E } \\
P\end{array}$ & $\begin{array}{l}0.60 \\
0.12\end{array}$ & $\begin{array}{l}0.54 \\
0.12\end{array}$ & $\begin{array}{c}0.55 \\
0.13 \\
--- \\
\end{array}$ & $\begin{array}{l}0.62 \\
0.14\end{array}$ & $\begin{array}{c}0.55 \\
0.12 \\
--- \\
\end{array}$ & $\begin{array}{c}0.55 \\
0.12 \\
--- \\
\end{array}$ \\
\hline $\begin{array}{l}\text { Hepato- } \\
\text { somatic } \\
\text { Index } \\
\end{array}$ & $\begin{array}{c}X \\
\text { S.E } \\
P \\
\end{array}$ & $\begin{array}{l}3.2 \\
0.19\end{array}$ & $\begin{array}{c}3.1 \\
0.10 \\
--- \\
\end{array}$ & $\begin{array}{c}3.1 \\
0.19 \\
---- \\
\end{array}$ & $\begin{array}{c}3 \\
0.10\end{array}$ & $\begin{array}{c}2.9 \\
0.10 \\
---- \\
\end{array}$ & $\begin{array}{l}2.98 \\
0.19 \\
---- \\
\end{array}$ \\
\hline $\begin{array}{c}\text { Gonado- } \\
\text { somatic } \\
\text { index }\end{array}$ & $\begin{array}{c}X \\
\text { S.E } \\
P\end{array}$ & $\begin{array}{l}1.07 \\
0.12\end{array}$ & $\begin{array}{c}.9 \\
0.15 \\
--- \\
\end{array}$ & $\begin{array}{c}0.95 \\
0.14 \\
--- \\
\end{array}$ & $\begin{array}{r}1.1 \\
0.12 \\
\end{array}$ & $\begin{array}{c}.95 \\
0.15 \\
---- \\
\end{array}$ & $\begin{array}{c}.94 \\
0.14 \\
----\end{array}$ \\
\hline
\end{tabular}


Table (2): Changes in respiration rate, heart beats and rectal temperature in control, treated with food additives and treated with (Food additives and royal jelly) in young rats after both treated and recovery periods.

\begin{tabular}{|c|c|c|c|c|c|c|c|}
\hline \multirow[b]{2}{*}{ Parameter } & & \multicolumn{3}{|c|}{ Treated period (1 month ) } & \multicolumn{3}{|c|}{ Recovery period (15 days) } \\
\hline & & Control & $\begin{array}{c}\mathrm{NaNo}_{3}+ \\
\text { S.S.Y }\end{array}$ & $\begin{array}{l}\mathrm{NaNo}_{3}+\mathrm{S} . \mathrm{S} . \mathrm{Y} . \\
\text { and royal jelly }\end{array}$ & Control & $\begin{array}{c}\mathrm{NaNo}_{3}+ \\
\text { S.S.Y. }\end{array}$ & $\begin{array}{c}\mathrm{NaNO}_{3}+\mathrm{S} . \mathrm{S} . \mathrm{Y} \\
\text { + Royal jelly }\end{array}$ \\
\hline $\begin{array}{c}\text { Respiration rate } \\
\text { (breath/min) }\end{array}$ & $\begin{array}{c}X \\
\text { S.E } \\
P\end{array}$ & $\begin{array}{l}49 \\
1.8\end{array}$ & $\begin{array}{c}65 \\
0.50 \\
<.01 \\
\end{array}$ & $\begin{array}{c}46.6 \\
1 \\
- \\
\end{array}$ & $\begin{array}{c}48.2 \\
1.2\end{array}$ & $\begin{array}{c}48.6 \\
0.90 \\
-\end{array}$ & $\begin{array}{c}45.8 \\
1.2 \\
- \\
\end{array}$ \\
\hline $\begin{array}{l}\text { Heart beats } \\
\text { (beat /min) }\end{array}$ & $\begin{array}{c}X \\
\text { S.E } \\
P\end{array}$ & $\begin{array}{l}136 \\
1.8\end{array}$ & $\begin{array}{c}139.6 \\
0.70 \\
-\end{array}$ & $\begin{array}{c}139.6 \\
1.1 \\
-\end{array}$ & $\begin{array}{l}134 \\
1.8\end{array}$ & $\begin{array}{c}133.6 \\
1.1 \\
-\end{array}$ & $\begin{array}{c}132.4 \\
1.1 \\
-\end{array}$ \\
\hline $\begin{array}{c}\text { Rectal } \\
\text { temperature, }{ }^{\circ} \mathrm{C}\end{array}$ & $\begin{array}{c}X \\
\text { S.E } \\
P\end{array}$ & $\begin{array}{c}34.72 \\
0.09\end{array}$ & $\begin{array}{c}34.54 \\
0.70 \\
-\end{array}$ & $\begin{array}{c}34.76 \\
0.30 \\
-\end{array}$ & $\begin{array}{l}34.64 \\
0.15\end{array}$ & $\begin{array}{c}33.94 \\
0.40 \\
-\end{array}$ & $\begin{array}{c}34.4 \\
0.30 \\
-\end{array}$ \\
\hline
\end{tabular}

Table (3): Changes in some haematological parameters (W.B.Cs, R.B.Cs, $\mathrm{Hb} \%$ and Hct\% in rats treated with food additives, food additives and royal jelly and their control after treated (30 days) and recovery (15 days) periods.

\begin{tabular}{|c|c|c|c|c|c|c|c|}
\hline \multirow[b]{2}{*}{ Parameter } & & \multicolumn{3}{|c|}{ Treated period (30 days ) } & \multicolumn{3}{|c|}{ Recovery period (15 days) } \\
\hline & & Control & $\begin{array}{c}\mathrm{NaNo}_{3}+ \\
\text { S.S.Y }\end{array}$ & $\begin{array}{l}\mathrm{NaNo}_{3}+\mathrm{S} . \mathrm{S} . \mathrm{Y} \\
\text { and royal jelly }\end{array}$ & Control & $\begin{array}{l}\mathrm{NaNo}_{3}+ \\
\text { S.S.Y. }\end{array}$ & $\begin{array}{c}\mathrm{NaNo}_{3}+\text { S.S.Y. } \\
\text { + Royal jelly }\end{array}$ \\
\hline $\begin{array}{c}\text { W.B.Cs } \\
\text { X10 }\end{array}$ & $\begin{array}{c}X \\
\text { S.E } \\
P\end{array}$ & $\begin{array}{c}8.5 \\
0.20\end{array}$ & $\begin{array}{c}6.9 \\
0.10 \\
<.01 \\
\end{array}$ & $\begin{array}{c}8.08 \\
0.10 \\
-\end{array}$ & $\begin{array}{l}8.82 \\
0.05\end{array}$ & $\begin{array}{l}7.16 \\
0.10 \\
<.01 \\
\end{array}$ & $\begin{array}{c}8.76 \\
0.09 \\
-\quad\end{array}$ \\
\hline $\begin{array}{c}\text { R.B.Cs } \\
\times 10^{3}\end{array}$ & $\begin{array}{c}X \\
\text { S.E } \\
P\end{array}$ & $\begin{array}{l}5.88 \\
0.05\end{array}$ & $\begin{array}{c}4.9 \\
0.05 \\
<.01\end{array}$ & $\begin{array}{c}5.9 \\
0.07 \\
-\end{array}$ & $\begin{array}{c}5.9 \\
0.07\end{array}$ & $\begin{array}{l}5.08 \\
0.06 \\
<.01\end{array}$ & $\begin{array}{c}5.88 \\
0.09 \\
-\end{array}$ \\
\hline $\mathrm{Hb} \%$ & $\begin{array}{c}X \\
\text { S.E } \\
P\end{array}$ & $\begin{array}{c}16 \\
0.10\end{array}$ & $\begin{array}{c}13.78 \\
0.10 \\
<.01\end{array}$ & $\begin{array}{l}15.98 \\
0.15\end{array}$ & $\begin{array}{c}15.82 \\
0.10\end{array}$ & $\begin{array}{l}14.2 \\
0.20 \\
<.01\end{array}$ & $\begin{array}{c}15.66 \\
0.09 \\
-\end{array}$ \\
\hline Hct \% & $\begin{array}{c}X \\
\text { S.E } \\
P\end{array}$ & $\begin{array}{l}41.4 \\
0.90\end{array}$ & $\begin{array}{l}36.8 \\
0.50 \\
<.01\end{array}$ & $\begin{array}{c}39.4 \\
0.70 \\
-\end{array}$ & $\begin{array}{c}42 \\
0.90\end{array}$ & $\begin{array}{l}37.2 \\
0.50 \\
<.01\end{array}$ & $\begin{array}{c}41 \\
0.80 \\
--\end{array}$ \\
\hline
\end{tabular}

Table (4): Biochemical and hormonal changes in serum of rats treated with food additives, food additives and royal jelly and their control after treated and recovery periods.

\begin{tabular}{|c|c|c|c|c|c|c|c|}
\hline \multirow[b]{2}{*}{ Parameter } & & \multicolumn{3}{|c|}{ Treated period } & \multicolumn{3}{|c|}{ Recovery period } \\
\hline & & Control & $\begin{array}{c}\mathrm{NaNo}_{3}+ \\
\text { S.S.Y }\end{array}$ & $\begin{array}{l}\mathrm{NaNO}_{3}+\mathrm{S} . \mathrm{S} . Y \\
\text { and royal jelly }\end{array}$ & Control & $\begin{array}{c}\mathrm{NaNo}_{3}+ \\
\text { S.S.Y }\end{array}$ & $\begin{array}{c}\mathrm{NaNo}_{3}+\text { S.S.Y. } \\
\text { + Royal jelly }\end{array}$ \\
\hline $\begin{array}{c}\text { Glucose } \\
\text { Mg/d L }\end{array}$ & $\begin{array}{c}X \\
\text { S.E } \\
P\end{array}$ & $\begin{array}{c}93.6 \\
2\end{array}$ & $\begin{array}{c}134.4 \\
1.9 \\
<.01\end{array}$ & $\begin{array}{c}90.2 \\
2.1 \\
-\end{array}$ & $\begin{array}{c}92.4 \\
1.7\end{array}$ & $\begin{array}{c}105.4 \\
1.7 \\
<.01\end{array}$ & $\begin{array}{c}8.9 \\
1.8 \\
-\end{array}$ \\
\hline $\begin{array}{c}\text { T3 } \\
\mathrm{mg} / \mathrm{d} \mathrm{L}\end{array}$ & $\begin{array}{c}X \\
\text { S.E } \\
P\end{array}$ & $\begin{array}{c}166 \\
1.8 \\
- \\
\end{array}$ & $\begin{array}{c}189 \\
1.8 \\
<.01\end{array}$ & $\begin{array}{c}162 \\
1.9 \\
- \\
\end{array}$ & $\begin{array}{c}157.8 \\
1.1\end{array}$ & $\begin{array}{c}168.8 \\
0.90 \\
<.01 \\
\end{array}$ & $\begin{array}{c}160 \\
1.5 \\
- \\
\end{array}$ \\
\hline $\begin{array}{c}\text { T4 } \\
\mathrm{mg} / \mathrm{d} \mathrm{L}\end{array}$ & $\begin{array}{c}X \\
\text { S.E } \\
P\end{array}$ & $\begin{array}{c}7.64 \\
0.30 \\
-\end{array}$ & $\begin{array}{l}9.5 \\
0.10 \\
<.01\end{array}$ & $\begin{array}{c}7.44 \\
0.20 \\
-\end{array}$ & $\begin{array}{l}6.84 \\
0.09\end{array}$ & $\begin{array}{l}7.4 \\
0.10 \\
<.01 \\
\end{array}$ & $\begin{array}{c}6.7 \\
0.12 \\
-\end{array}$ \\
\hline $\begin{array}{l}\text { Calcium } \\
\text { mg/d L }\end{array}$ & $\begin{array}{c}X \\
\text { S.E } \\
P\end{array}$ & $\begin{array}{c}7.9 \\
0.20 \\
-\end{array}$ & $\begin{array}{l}9.875 \\
0.20 \\
<.01 \\
\end{array}$ & $\begin{array}{c}7.82 \\
0.20 \\
- \\
\end{array}$ & $\begin{array}{l}7.5 \\
0.18\end{array}$ & $\begin{array}{l}8.7 \\
0.20 \\
<.01 \\
\end{array}$ & $\begin{array}{c}7.48 \\
0.20 \\
- \\
\end{array}$ \\
\hline $\begin{array}{l}\text { Inorganic } \\
\text { phosphorus mg/d } \\
\mathrm{L}\end{array}$ & $\begin{array}{c}X \\
\text { S.E } \\
P\end{array}$ & $\begin{array}{c}12.04 \\
0.18 \\
- \\
\end{array}$ & $\begin{array}{l}9.9 \\
0.20 \\
<.01\end{array}$ & $\begin{array}{c}10.94 \\
0.20 \\
<.01\end{array}$ & $\begin{array}{c}11.94 \\
0.18\end{array}$ & $\begin{array}{l}10.8 \\
0.20 \\
<.01\end{array}$ & $\begin{array}{c}11.6 \\
0.18 \\
-\end{array}$ \\
\hline
\end{tabular}


Table (5): AST activity in serum, liver, muscle, kidney and heart in food additives, food additives and royal-jelly treated rats in comparison with their control after treated and recovery periods

\begin{tabular}{|c|c|c|c|c|c|c|c|}
\hline \multirow[b]{2}{*}{ Parameter } & & \multicolumn{3}{|c|}{ Treated period ( 30 days) } & \multicolumn{3}{|c|}{ Recovery period (15days) } \\
\hline & & Control & $\begin{array}{l}\mathrm{NaNo}_{3}+ \\
\text { S.S.Y }\end{array}$ & $\begin{array}{c}\mathrm{NaNo}_{3}+\mathrm{S} . \mathrm{S} . \mathrm{Y} \text { and } \\
\text { royal jelly }\end{array}$ & Control & $\begin{array}{l}\mathrm{NaNo}_{3}+ \\
\text { S.S.Y }\end{array}$ & $\begin{array}{l}\mathrm{NaNo}_{3}+\mathrm{S} . \mathrm{S} . \mathrm{Y} \\
+ \text { Royal jelly }\end{array}$ \\
\hline $\begin{array}{c}\text { Serum } \\
\text { AST } \\
\text { u/L }\end{array}$ & $\begin{array}{c}X \\
\text { S.E } \\
P\end{array}$ & $\begin{array}{l}23.8 \\
0.70\end{array}$ & $\begin{array}{c}37 \\
1.2 \\
\text { normal value }\end{array}$ & $\begin{array}{c}21.6 \\
0.90 \\
\text { normal value }\end{array}$ & $\begin{array}{c}21.2 \\
1\end{array}$ & $\begin{array}{c}27.4 \\
1 \\
\text { normal value }\end{array}$ & $\begin{array}{c}18.4 \\
0.90 \\
\text { normal value }\end{array}$ \\
\hline $\begin{array}{c}\text { Brain } \\
\text { AST } \\
\mathbf{u} / \mathrm{g}\end{array}$ & $\begin{array}{c}X \\
\text { S.E } \\
P\end{array}$ & $\begin{array}{c}15 \\
0.40\end{array}$ & $\begin{array}{c}24.4 \\
0.90 \\
\text { normal value }\end{array}$ & $\begin{array}{r}16.5 \\
0.60 \\
\text { normal value }\end{array}$ & $\begin{array}{c}14 \\
0.70\end{array}$ & $\begin{array}{c}21.6 \\
0.50 \\
\text { normal value }\end{array}$ & $\begin{array}{c}16 \\
0.80 \\
\text { normal value }\end{array}$ \\
\hline $\begin{array}{l}\text { Liver } \\
\text { AST } \\
\text { u/g }\end{array}$ & $\begin{array}{c}X \\
\text { S.E } \\
P\end{array}$ & $\begin{array}{l}18 \\
1.1\end{array}$ & $\begin{array}{c}26.2 \\
0.50 \\
\text { normal value. }\end{array}$ & $\begin{array}{c}18 \\
0.50 \\
\text { normal value }\end{array}$ & $\begin{array}{l}17.2 \\
0.80\end{array}$ & $\begin{array}{c}17.2 \\
1.1 \\
\text { normal value }\end{array}$ & $\begin{array}{c}17 \\
0.60 \\
\text { normal value }\end{array}$ \\
\hline 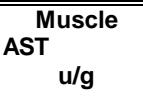 & $\begin{array}{c} \\
\text { S.E } \\
P\end{array}$ & $\begin{array}{c}16.6 \\
1.4\end{array}$ & $\begin{array}{c}21 \\
1.1 \\
\text { normal value }\end{array}$ & $\begin{array}{c}17 \\
0.90 \\
\text { normal value }\end{array}$ & $\begin{array}{c}16.8 \\
1.7\end{array}$ & $\begin{array}{c}14.8 \\
0.90 \\
\text { normal value. }\end{array}$ & $\begin{array}{c}15 \\
0.40 \\
\text { normal value }\end{array}$ \\
\hline $\begin{array}{c}\text { Kidney } \\
\text { AST } \\
\text { u/g }\end{array}$ & $\begin{array}{c}X \\
\text { S.E } \\
P\end{array}$ & $\begin{array}{l}16.8 \\
1.2\end{array}$ & $\begin{array}{c}23 \\
1.5 \\
\text { normal value. }\end{array}$ & $\begin{array}{c}14 \\
0.20 \\
\text { normal value }\end{array}$ & $\begin{array}{c}17 \\
0.70\end{array}$ & $\begin{array}{c}16.6 \\
1.6 \\
\text { normal value }\end{array}$ & $\begin{array}{c}15.2 \\
0.80 \\
\text { normal value }\end{array}$ \\
\hline $\begin{array}{l}\text { Heart } \\
\text { AST } \\
\text { u/g }\end{array}$ & $\begin{array}{c}X \\
\text { S.E } \\
P\end{array}$ & $\begin{array}{l}13.4 \\
0.50\end{array}$ & $\begin{array}{c}20.6 \\
1.4 \\
\text { normal value }\end{array}$ & $\begin{array}{c}18 \\
0.08 \\
\text { normal value }\end{array}$ & $\begin{array}{l}13.8 \\
0.90\end{array}$ & $\begin{array}{c}18.4 \\
0.70 \\
\text { normal value }\end{array}$ & $\begin{array}{c}15 \\
0.30 \\
\text { normal value }\end{array}$ \\
\hline
\end{tabular}

Table (6): ALT activity in serum of rats, in brain, liver, muscle, kidney and heart treated with food additives or food additives and royal jelly and their control after treated and recovery periods.

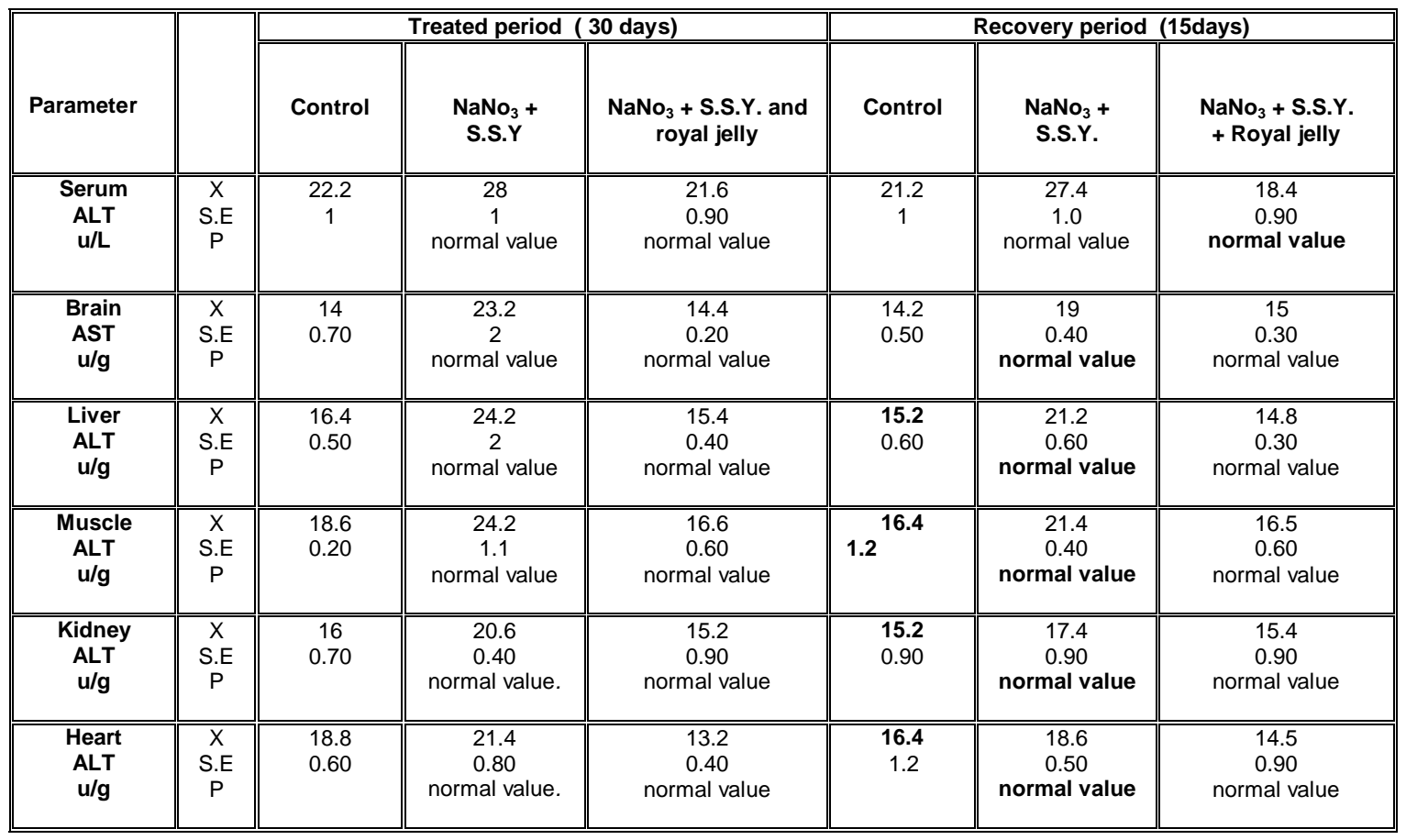




\section{Eman G. E. Helal}

Table (7): Some serum enzyme activities in rats treated with food additives and royal-jelly and their control after both treated and recovery periods.

\begin{tabular}{|c|c|c|c|c|c|c|c|}
\hline \multirow[b]{2}{*}{ Parameter } & & \multicolumn{3}{|c|}{ Treated period (1 month ) } & \multicolumn{3}{|c|}{ Recovery period (15days) } \\
\hline & & Control & $\underset{\text { S.S.Y }}{\mathrm{NaNo}_{3}+}$ & $\begin{array}{l}\mathrm{NaNO}_{3}+\mathrm{S} . \mathrm{S} . \mathrm{Y} \\
\text { and royal jelly }\end{array}$ & Control & $\underset{\text { S.S.Y }}{\mathrm{NaNO}_{3}+}$ & $\begin{array}{c}\mathrm{NaNo}_{3}+\mathrm{S} . \mathrm{S} . \mathrm{Y} \\
\mathrm{Royal} \text { jelly }\end{array}$ \\
\hline $\begin{array}{c}Y-G T \\
u / L\end{array}$ & $\begin{array}{c}\text { S.E } \\
\text { P }\end{array}$ & $\begin{array}{l}16.8 \\
0.70\end{array}$ & $\begin{array}{l}37.2 \\
0.90 \\
<.01 \\
\end{array}$ & $\begin{array}{c}18.4 \\
0.80 \\
- \\
\end{array}$ & $\begin{array}{l}16.8 \\
0.50\end{array}$ & $\begin{array}{c}31 \\
0.40 \\
<.01\end{array}$ & $\begin{array}{c}18.4 \\
0.60 \\
-\end{array}$ \\
\hline $\begin{array}{l}\text { LDH } \\
\mathrm{u} / \mathrm{L}\end{array}$ & $\begin{array}{c}X \\
\text { S.E } \\
P \\
\end{array}$ & $\begin{array}{l}245 \\
2.2\end{array}$ & $\begin{array}{c}266 \\
2.4 \\
<.01 \\
\end{array}$ & $\begin{array}{c}250 \\
2.2 \\
- \\
\end{array}$ & $\begin{array}{l}244 \\
2.4\end{array}$ & $\begin{array}{c}244 \\
2.4 \\
- \\
\end{array}$ & $\begin{array}{c}239 \\
1.8 \\
- \\
\end{array}$ \\
\hline $\begin{array}{l}\text { CPK } \\
\text { u/L }\end{array}$ & $\begin{array}{c}X \\
\text { S.E } \\
P\end{array}$ & $\begin{array}{l}55 \\
2.2\end{array}$ & $\begin{array}{c}74 \\
2.4 \\
<.01\end{array}$ & $\begin{array}{c}54 \\
2.4 \\
-\end{array}$ & $\begin{array}{l}54 \\
1.8\end{array}$ & $\begin{array}{c}63 \\
2 \\
<.01\end{array}$ & $\begin{array}{c}54.2 \\
1.9 \\
-\end{array}$ \\
\hline $\begin{array}{c}\text { Alk ph/ } \\
\text { u/L }\end{array}$ & $\begin{array}{c}X \\
S . E \\
P \\
\end{array}$ & $\begin{array}{c}96 \\
0.60\end{array}$ & $\begin{array}{l}106 \\
1.8 \\
<.01 \\
\end{array}$ & $\begin{array}{c}93 \\
2.2 \\
- \\
\end{array}$ & $\begin{array}{l}91 \\
0.90\end{array}$ & $\begin{array}{c}115 \\
\\
2.2 \\
<.01 \\
\end{array}$ & $\begin{array}{c}94 \\
2.4 \\
- \\
\end{array}$ \\
\hline $\begin{array}{l}\text { Acid ph. } \\
\text { u/L }\end{array}$ & $\begin{array}{c}X \\
\text { S.E } \\
P\end{array}$ & $\begin{array}{c}9 \\
0.40\end{array}$ & $\begin{array}{l}10.6 \\
0.40\end{array}$ & $\begin{array}{c}10 \\
0.30 \\
-\end{array}$ & $\begin{array}{c}10.36 \\
0.20\end{array}$ & $\begin{array}{c}11.3 \\
0.30 \\
-\end{array}$ & $\begin{array}{c}10.6 \\
0.20 \\
-\end{array}$ \\
\hline
\end{tabular}

Table (8): Protein contents of serum and some organs in rats treated with food additives or food additives and royal jelly and their control after treated and recovery periods.

\begin{tabular}{|c|c|c|c|c|c|c|c|}
\hline \multirow[b]{2}{*}{ Parameter } & & \multicolumn{3}{|c|}{ Treated period ( 30 days ) } & \multicolumn{3}{|c|}{ Recovery period (15days) } \\
\hline & & Control & Treated & $\begin{array}{c}\text { Treated + } \\
\text { R.J }\end{array}$ & Control & Treated & $\begin{array}{c}\text { Treated + } \\
\text { R.J }\end{array}$ \\
\hline $\begin{array}{c}\text { Serum } \\
\text { Protein } \\
\text { g/dL }\end{array}$ & $\begin{array}{c}X \\
S . E \\
P\end{array}$ & $\begin{array}{l}8.34 \\
0.30\end{array}$ & $\begin{array}{l}6.48 \\
.030 \\
<.01\end{array}$ & $\begin{array}{c}7.8 \\
0.20 \\
-\end{array}$ & $\begin{array}{c}7.9 \\
0.16\end{array}$ & $\begin{array}{c}7.78 \\
0.19 \\
-\end{array}$ & $\begin{array}{c}7.7 \\
0.15 \\
-\end{array}$ \\
\hline $\begin{array}{c}\text { Brain } \\
\text { Protein } \\
\mathrm{mg} / \mathrm{g}\end{array}$ & $\begin{array}{c}X \\
S . E \\
P\end{array}$ & $\begin{array}{c}110.4 \\
0.60\end{array}$ & $\begin{array}{c}110 \\
0.70 \\
-\end{array}$ & $\begin{array}{c}110.6 \\
0.20 \\
-\end{array}$ & $\begin{array}{l}110 \\
0.70\end{array}$ & $\begin{array}{c}110.5 \\
0.80 \\
-\end{array}$ & $\begin{array}{c}110.4 \\
0.40 \\
-\end{array}$ \\
\hline $\begin{array}{c}\text { Liver } \\
\text { Protein } \\
\mathrm{mg} / \mathrm{g}\end{array}$ & $\begin{array}{c}X \\
\text { S.E } \\
P\end{array}$ & $\begin{array}{l}56 \\
1.8\end{array}$ & $\begin{array}{c}55 \\
2.2 \\
-\end{array}$ & $\begin{array}{c}57 \\
3 \\
-\end{array}$ & $\begin{array}{l}50 \\
3.5\end{array}$ & $\begin{array}{c}53.6 \\
2.4 \\
-\end{array}$ & $\begin{array}{c}55.2 \\
1.5 \\
-\end{array}$ \\
\hline $\begin{array}{c}\text { Muscle } \\
\text { Protein } \\
\mathrm{mg} / \mathrm{g}\end{array}$ & $\begin{array}{c}X \\
\text { S.E } \\
P\end{array}$ & $\begin{array}{l}92 \\
1.2\end{array}$ & $\begin{array}{l}90.8 \\
0.90\end{array}$ & $\begin{array}{c}92.6 \\
1.1 \\
-\end{array}$ & $\begin{array}{l}92.4 \\
0.40\end{array}$ & $\begin{array}{c}91.4 \\
0.90 \\
-\end{array}$ & $\begin{array}{c}92.2 \\
1.1 \\
-\end{array}$ \\
\hline $\begin{array}{c}\text { Kidney } \\
\text { Protein } \\
\mathrm{mg} / \mathrm{g}\end{array}$ & $\begin{array}{c}X \\
\text { S.E } \\
P\end{array}$ & $\begin{array}{l}68.4 \\
0.90\end{array}$ & $\begin{array}{c}64.4 \\
2.1 \\
-\end{array}$ & $\begin{array}{c}66.4 \\
2.1 \\
-\end{array}$ & $\begin{array}{c}67.6 \\
1\end{array}$ & $\begin{array}{c}64.2 \\
1.5 \\
-\end{array}$ & $\begin{array}{c}65.4 \\
0.60 \\
-\end{array}$ \\
\hline $\begin{array}{c}\text { Heart } \\
\text { Protein } \\
\mathrm{mg} / \mathrm{g}\end{array}$ & $\begin{array}{c}X \\
\text { S.E } \\
P\end{array}$ & $\begin{array}{c}88 \\
0.90\end{array}$ & $\begin{array}{c}85.2 \\
1.5 \\
-\end{array}$ & $\begin{array}{c}85.2 \\
1.4 \\
-\end{array}$ & $\begin{array}{l}87 \\
1.1\end{array}$ & $\begin{array}{c}88.6 \\
0.40 \\
-\end{array}$ & $\begin{array}{c}85.4 \\
0.50 \\
-\end{array}$ \\
\hline $\begin{array}{c}\text { Serum } \\
\text { Albumin } \\
\text { g/dL }\end{array}$ & $\begin{array}{c}X \\
S . E \\
P\end{array}$ & $\begin{array}{l}5.54 \\
0.10\end{array}$ & $\begin{array}{l}4.22 \\
0.10 \\
<.01\end{array}$ & $\begin{array}{c}5.76 \\
14 \\
-\end{array}$ & $\begin{array}{c}4.9 \\
0.14\end{array}$ & $\begin{array}{c}4.84 \\
0.09 \\
-\end{array}$ & $\begin{array}{c}5.06 \\
0.09 \\
-\end{array}$ \\
\hline $\begin{array}{c}\text { Serum } \\
\text { Globulin } \\
\text { g/dL }\end{array}$ & $\begin{array}{c}X \\
S . E \\
P\end{array}$ & $\begin{array}{l}2.71 \\
0.13\end{array}$ & $\begin{array}{l}2.41 \\
0.17\end{array}$ & $\begin{array}{l}1.84 \\
0.10\end{array}$ & $\begin{array}{c}3.1 \\
0.10\end{array}$ & $\begin{array}{l}2.6 \\
0.18 \\
<.05\end{array}$ & $\begin{array}{l}2.04 \\
0.10 \\
<.05\end{array}$ \\
\hline $\bar{A} / \mathbf{G}$ & $\begin{array}{c}X \\
\text { S.E } \\
P\end{array}$ & $\begin{array}{l}2.04 \\
0.10\end{array}$ & $\begin{array}{l}1.98 \\
0.18\end{array}$ & $\begin{array}{l}3.3 \\
0.12 \\
<.05\end{array}$ & $\begin{array}{l}1.58 \\
0.10\end{array}$ & $\begin{array}{l}1.76 \\
0.22\end{array}$ & $\begin{array}{l}2.66 \\
0.10 \\
<.01\end{array}$ \\
\hline
\end{tabular}


Table (9): Total lipids level of serum and some organs in rats treated with food additives or food additives and royal jelly and their control after treated and recovery periods.

\begin{tabular}{|c|c|c|c|c|c|c|c|}
\hline \multirow[b]{2}{*}{ Parameter } & & \multicolumn{3}{|c|}{ Treated period ( 30 days ) } & \multicolumn{3}{|c|}{ Recovery period (15days) } \\
\hline & & Control & $\begin{array}{c}\mathrm{NaNO}_{3}+ \\
\text { S.S.Y }\end{array}$ & $\begin{array}{l}\mathrm{NaNO}_{3}+\mathrm{S} . \mathrm{S} . \mathrm{Y} \\
\text { and royal jelly }\end{array}$ & Control & $\begin{array}{c}\mathrm{NaNO}_{3}+ \\
\text { S.S.Y }\end{array}$ & $\begin{array}{l}\mathrm{NaNO}_{3}+\mathrm{S} . \mathrm{S} . \mathrm{Y} \\
+ \text { Royal jelly }\end{array}$ \\
\hline $\begin{array}{l}\text { Serum } \\
\text { Total lipids } \\
\text { g/dL }\end{array}$ & $\begin{array}{l}\mathrm{X} \\
\mathrm{S} . \\
\mathrm{E} \\
\mathrm{P}\end{array}$ & $\begin{array}{l}388 \\
4.8\end{array}$ & $\begin{array}{l}390 \\
5.1 \\
-\end{array}$ & $\begin{array}{l}382 \\
4.8\end{array}$ & $\begin{array}{l}382 \\
7.3\end{array}$ & $\begin{array}{l}388 \\
7.3\end{array}$ & $\begin{array}{l}368 \\
5.8\end{array}$ \\
\hline $\begin{array}{c}\text { Brain } \\
\text { Total lipids } \\
\text { Mg/g }\end{array}$ & $\begin{array}{l}X \\
S . \\
E \\
P\end{array}$ & $\begin{array}{l}49 \\
1.8\end{array}$ & $\begin{array}{c}58 \\
4.1 \\
-\end{array}$ & $\begin{array}{c}53 \\
2.2 \\
-\end{array}$ & $\begin{array}{c}51.6 \\
2.6\end{array}$ & $\begin{array}{c}52 \\
2.5 \\
-\end{array}$ & $\begin{array}{l}49.4 \\
0.40 \\
-\end{array}$ \\
\hline $\begin{array}{c}\text { Liver } \\
\text { Total lipids } \\
\text { mg/g }\end{array}$ & $\begin{array}{l}X \\
S . \\
E \\
P\end{array}$ & $\begin{array}{c}92.6 \\
2.8\end{array}$ & $\begin{array}{c}99 \\
2.4 \\
-\end{array}$ & $\begin{array}{c}95.6 \\
1.7 \\
-\end{array}$ & $\begin{array}{l}92 \\
2.5\end{array}$ & $\begin{array}{l}96 \\
1.4 \\
-\end{array}$ & $\begin{array}{l}96.8 \\
0.60 \\
-\end{array}$ \\
\hline $\begin{array}{c}\text { Muscle } \\
\text { Total lipids } \\
\text { mg/g }\end{array}$ & $\begin{array}{l}X \\
S . \\
E \\
P\end{array}$ & $\begin{array}{c}46.4 \\
2.7\end{array}$ & $\begin{array}{c}56.2 \\
4.1 \\
-\end{array}$ & $\begin{array}{c}47 \\
3 \\
-\end{array}$ & $\begin{array}{l}45 \\
2.8\end{array}$ & $\begin{array}{c}47 \\
1.2 \\
-\end{array}$ & $\begin{array}{c}43.4 \\
1.8 \\
-\end{array}$ \\
\hline $\begin{array}{c}\text { Kidney } \\
\text { Total lipids } \\
\text { mg/g }\end{array}$ & $\begin{array}{l}\mathrm{X} \\
\mathrm{S} . \\
\mathrm{E} \\
\mathrm{P}\end{array}$ & $\begin{array}{c}44.4 \\
1.5\end{array}$ & $\begin{array}{c}53.2 \\
3.8 \\
-\end{array}$ & $\begin{array}{c}44 \\
0.60 \\
-\end{array}$ & $\begin{array}{l}45 \\
1.4\end{array}$ & $\begin{array}{c}48.2 \\
1.3 \\
-\end{array}$ & $\begin{array}{l}42.8 \\
0.60 \\
-\end{array}$ \\
\hline $\begin{array}{c}\text { Heart } \\
\text { Total lipids } \\
\text { mg/g }\end{array}$ & $\begin{array}{l}X \\
S . \\
E \\
P\end{array}$ & $\begin{array}{c}53.6 \\
1.8\end{array}$ & $\begin{array}{c}55.8 \\
2.3\end{array}$ & $\begin{array}{l}50.2 \\
0.50\end{array}$ & $\begin{array}{c}49.6 \\
2.2\end{array}$ & $\begin{array}{c}44.8 \\
5.2\end{array}$ & $\begin{array}{c}45.4 \\
1.6\end{array}$ \\
\hline
\end{tabular}

Table (10): Cholesterol level of serum and some organs in rats treated with food additives or food additives and royal jelly and their control after treated and recovery periods.

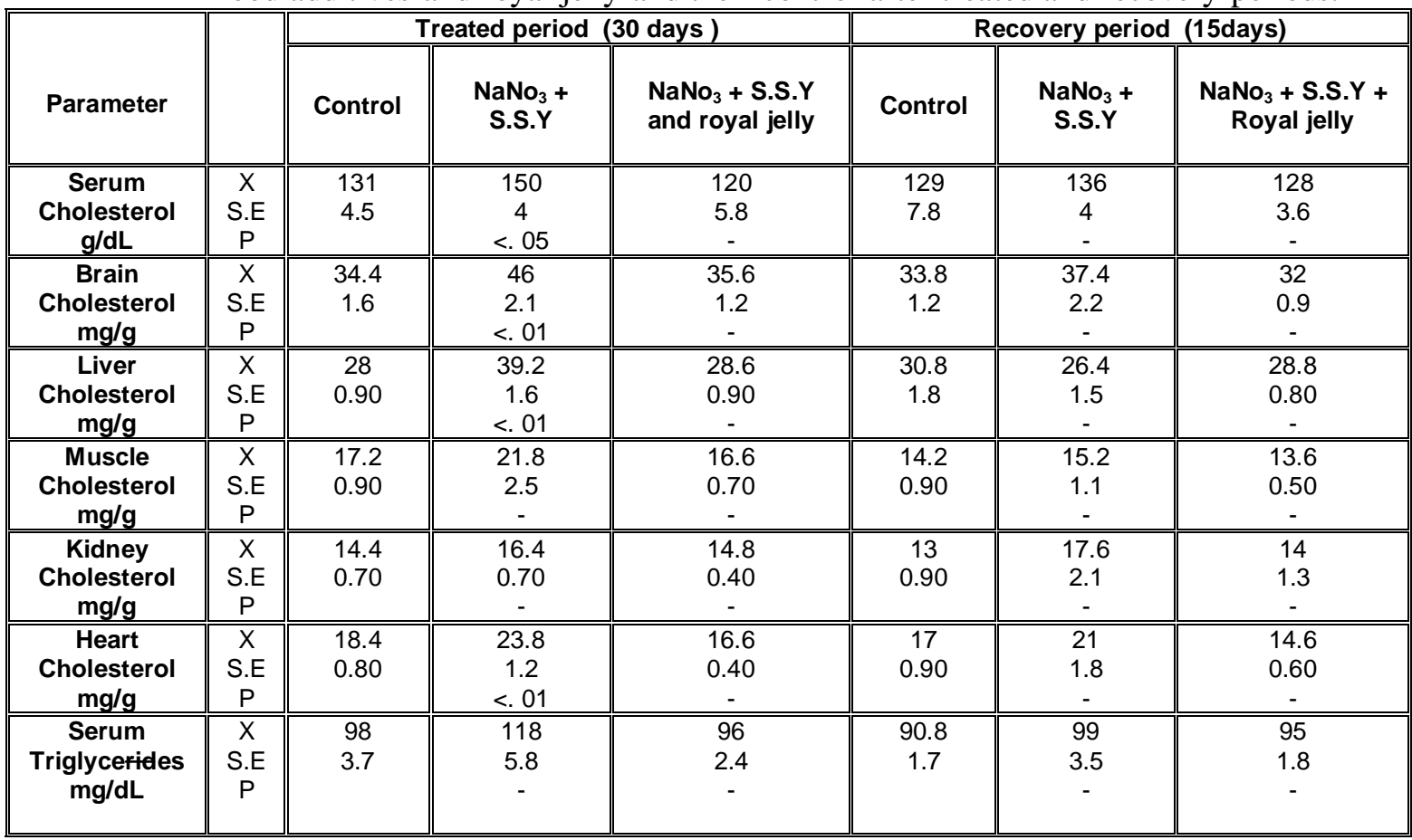




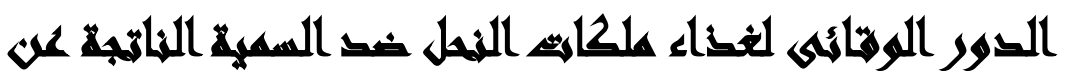

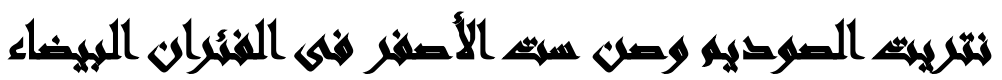

\author{
إيمان جمال الدين عزت هلال \\ قسم علم الحيوان - كلية العلوم (بنات) - جامعة الأزهر
}

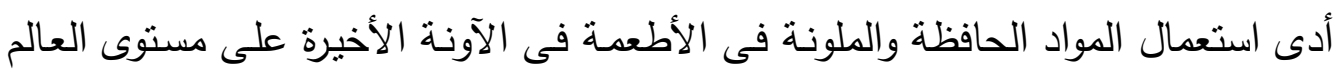

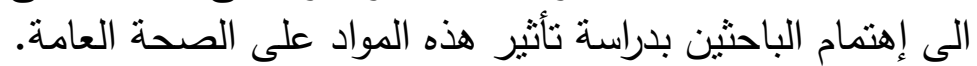

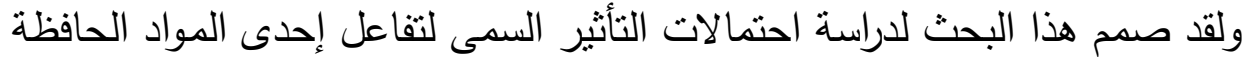

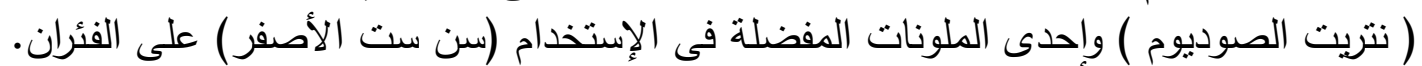

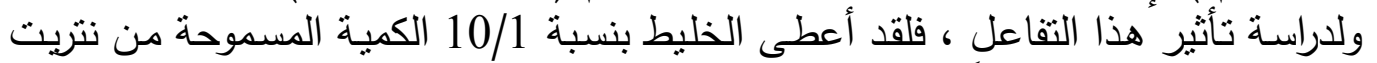

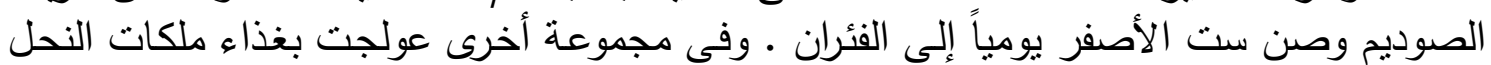

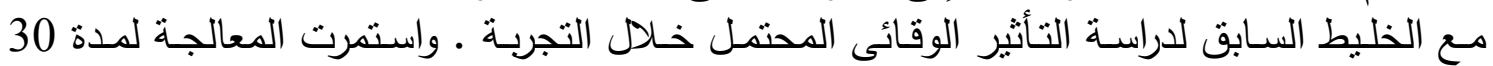

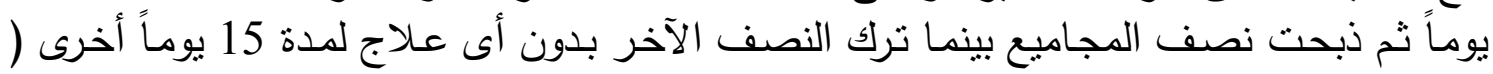

كفترة استشفاء ).

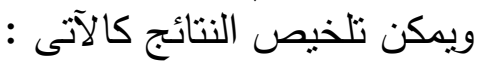

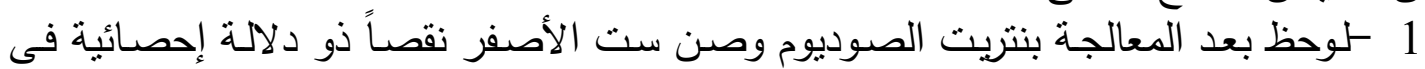

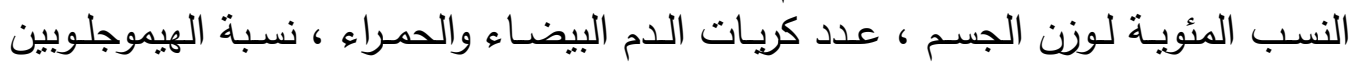

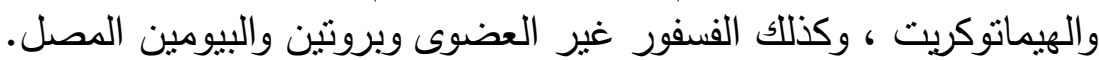

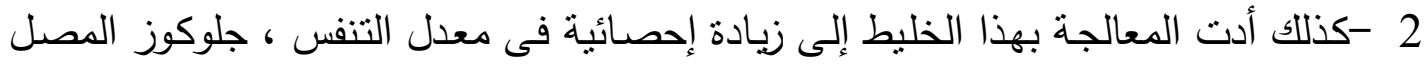

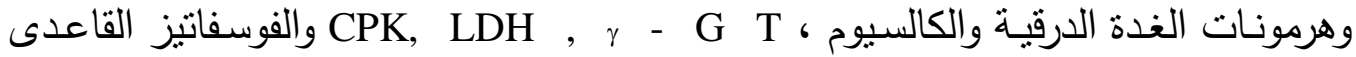

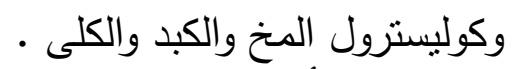

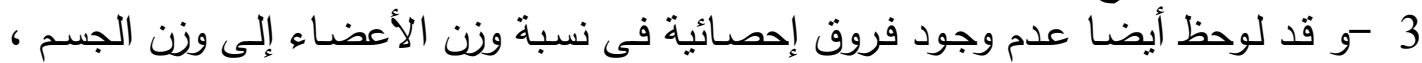

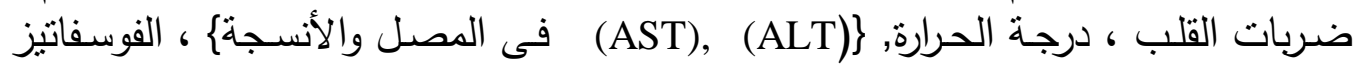

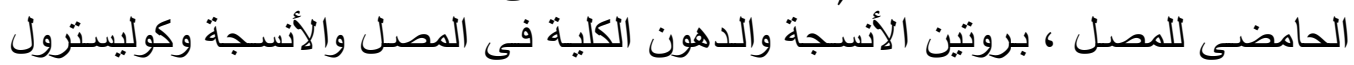

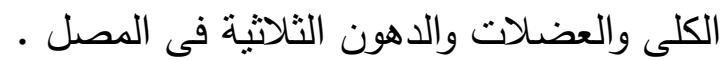
4 - كولقد كانت المعالجة بغذاء ملكات النحل وكذللك فترة الاستتفاء ذو أثر وقائى مضاد لسمية هذه المضافات .

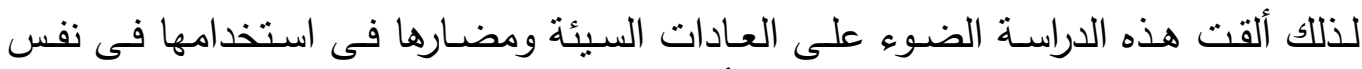

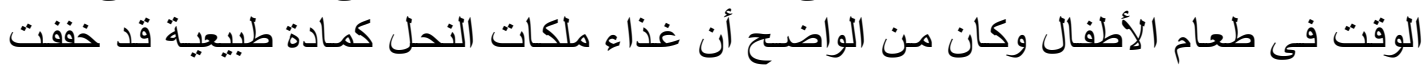

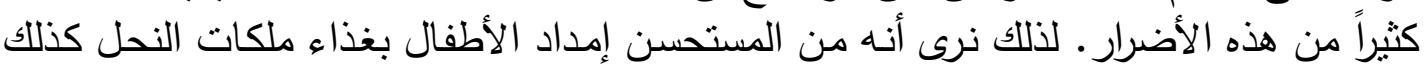

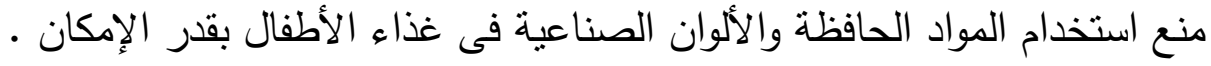

